ISSN 2413-0877 Volume 1 (2015)

The 1st International Symposium on Aquatic Product Processing 2013

\title{
HEPATOPROTECTIVE EFFECTS ETHANOL EXTRACT OF MAGROVE PROPAGULE (Rhizophora mucronata) IN WHITE RAT STRAIN Sprague Dawley INDUCED CARBON TETRACHLORIDE (CCL4)
}

\section{Sri Purwaningsih'), Ekowati Handharyani2), Aditya Yudha Prawira Sukarno1)}

\author{
1)Aquatic Product Technology Studies Program, Faculty of Fisheries and \\ Marine Science, Bogor Agricultural University, Indonesia \\ 2)Clinical Pathology, Faculty of Veterinary Medicine, \\ Bogor Agricultural University, Indonesia
}

\begin{abstract}
Prevalence of liver disease more increased. Imfflamation in liver tissue caused by free radical metabolism results of toxic compounds such as alcohol, paracetamol, and carbon tetrachloride $\left(\mathrm{CCL}_{4}\right)$. Rhizophora mucronata has been higher antioxidant activities and reported as hepatoprotector. This research was aimed to investigate activity of mangrove propagule (R.mucronata) as a hepatoprotector and determined the effect levels of specific liver enzymes, liver MDA, and histopathological studies. Rhizophora mucronata was extracted by ethanol $95 \%$ solvent $(\mathrm{b}: \mathrm{v})(1: 5)$. There were 21 rats randomly divided into 7 following groups $(n=3)$, they were group I allowed fed with standard pellet, group II was positive control induced $C C L 4$ dose $2 \mathrm{ml} / \mathrm{kg} \mathrm{BW}$, group III, IV, V, and VI were induced by $C C L$ dose $2 \mathrm{ml} / \mathrm{kg} B W$ and given consecutively the mangrove extract $1 \mathrm{mg} / \mathrm{kg} \mathrm{BW}, 5 \mathrm{mg} / \mathrm{kg} \mathrm{BW}, 15 \mathrm{mg} / \mathrm{kg} \mathrm{BW}$, and 25 $\mathrm{mg} / \mathrm{kg} \mathrm{BW}$. Result showed the extract did not affect significantly $(p>0.05)$ to decreased level of AST enzyme and the best value owned of $15 \mathrm{mg} / \mathrm{kg} \mathrm{BW}$ treatment with AST levels as 187 U/L. In contrast, extract R.mucronata effected significantly different $(p<0.05)$ on ALT levels with the best value in $5 \mathrm{mg} / \mathrm{kg}$ BW treatment. R.mucronata did not effect significantly ( $p>0.05$ ) of MDA level in liver, and decreased with the best result in $5 \mathrm{mg} / \mathrm{kg} \mathrm{BW}$ treatment. Histopatological studies showed a protective effect and cell recovery of the liver induced CCL4.
\end{abstract}

Keywords: Antoxidant, Hepatoprotective, Mangrove propagule (R.mucronata)

\section{INTRODUCTION}

Liver disease is a disease that is common in Indonesia. Epidemiologically Indonesian including moderate to high endemic areas of hepatitis $B$ in the world (WHO 2012). Approximately 300-350 million people was infected with hepatitis B and $78 \%$ among in Asia. As much as 170 million people are infected with hepatitis $C$ with a mortality rate more than 350 thousand per year. In 2012, Indonesia's population is suffering from hepatitis B and C more than 20 million people (Ministry of Health 2012). Two types of the disease is often associated with liver disease (cirrhosis). Cirrhosis can progress to liver cancer. Cirrhosis or liver cancer will end with the death of the sufferer.

Liver disease or more known as hepatitis is an inflammation of the liver tissue. The caused of liver function damage can be caused by viruses, bacteria aflatoxin, prolonged consumption of alcohol and drugs that enter the body with a variety of mechanisms (Nugroho et al. 2008). The liver is the very important organt and has a variety functions in the 
metabolic process so that these organs are often exposed to chemicals. These chemicals will have detoksication and inactivation so that be not harmful for body. Liver damage due to drug and chemical substances may occur if the backup of durability liver and reduced liver cell regeneration ability, and then will cause permanent damage (Brick 2004). The largest body's organ is the major site of xenobiotic metabolism and became the first target organ hepatoksikan like alcohol, paracetamol, $\mathrm{CCl} 4$, and other chemical compounds that will produce metabolite acetaldehyde which have highly toxic (Hudgson 2004).

Until now there is no satisfactory natural medicine for the disease (damage) of the liver. While there, Beside rudimentary healing properties, these drugs also have harmful side effects because it contained a lot of chemical components. In addition, the expensive of drugs price still be a major obstacle in the treatment of liver disease. The one hope, the alternative source of new natural hepatoprotektan is mangrove fruit (Rhizhopora mucronata). Previous studies stated that mangrove fruit has high antioxidant activity with IC50 value in amount of 58.61 ppm (Priyatno 2012), with high antioxidant activity indicated that the fruit mangrove may be natural hepatoprotective. Antioxidants is compound that neutralize free radical. According Nugraha et al (2008) fruit with a high content of antioxidant compounds may have a hepatoprotective activity because it can reduce free radical metabolites of peroxide triklometil result from $\mathrm{CCl} 4$ transformation. According Rohaeti et al. (2010) mangrove fruit also has several active compounds, namely flavonoid, saponin, tannin, and triterpenoid. Ravikumar \& Gnanadesigan (2012) said that the presence of chemical compounds such as flavonoid, triterpenoid, tannin, and alkaloid that exist in mangrove fruit allows the hepatoprotective mechanism by inhibited of P450 cytochrome in the metabolism of free radical triklorometil formation. Mangrove fruit (Rhizhopora mucronata) have sufficient availability in nature, because these fruit produced throughout the year (FAO 2000). The results of this study are expected to provided scientific information on antioxidant properties of the mangrove fruit (Rhizophora mucronata) in vivo, and can be used as a basis for development of mangrove fruit plant into drugs products that can be used widely by community. This study aimed to determined the antioxidant activity and hepatoprotective effect of fruit mangrove (Rhizophora mucronata).

\section{MATERIAL AND METHODS}

The experiment was performed in February until August 2013. The study was performed in several laboratories, the Laboratory of Water Result Biochemistry, Department of Aquatic Product Technology for the preparation, characterization, extraction and phytochemical analysis. Analysis of hepatoprotective effects of mangrove fruit extract (Rhizhopora mucronata) test in vivo performed in IPB Animal Hospital, Dramaga Medialisa laboratory, and part of Pathology, Faculty of Veterinary Medicine, Bogor Agricultural Institute. 


\section{Material and Equipment}

The main material that are used was the fruit of mangrove (Rhizhopora mucronata). The materials that are needed for proximate analysis include akuades, kjeltab selenium species, concentrated $\mathrm{H} 2 \mathrm{SO} 4$ p.a. solution, boric acid ( $\mathrm{H} 3 \mathrm{BO} 3$ ) $4 \%$ containing bromcherosol greenmethyl red (1:2) pink indicator, $0.0947 \mathrm{~N} \mathrm{HCl}$ solution, fat solvents (n-hexane p.a. ), $10 \% \mathrm{HCl}$ solution and a solution of AgNO3 0,10 N. The material that are used for extraction was $95 \%$ ethanol. The materials that are used for the analysis of antioxidant activity was 1.1-diphenyl2-picrylhdrazyl methanol, and vitamin $C$ as a positive control. The materials that are needed for phytochemical test include Wagner reagents, Meyer reagents, Dragendroff reagents, chloroform, acetic anhydride, concentrated sulfuric acid, magnesium powder, amyl alcohol, hot water, $\mathrm{HCl} 2 \mathrm{~N}$ solution, $95 \%$ ethanol , $5 \% \mathrm{FeCl} 3$ solution, Molisch reagents, concentrated sulfuric acid, Benedict reagents, Biuret reagent, and $0.10 \%$ Ninhydrin solution. While the materials that are used in hepatoprotective effect test in vivo was karbontetraklorida (CCl4), paraffin, fisiologic $\mathrm{NaCl}$, neutral buffered formalin $10 \%$, xilol, paraffin, hematoxylin-eosin (HE), phosphate buffer, potassium chloride, HCL, trichloroacetic, butilat hydroxytoluene, tiobarbiturat acid, hydrochloric acid, tetraetoksipropana.

The tools that are needed in the study include a ruler, knife, spatula, cup porcelain, digital scales, glass bottles and jars of small films, oven, microtome Yamato RV-240, hot plate, glass objects, shelf dyes, Olympus $\mathrm{CH} 20$ types of light microscope and Olympus DP1 2 microscope camera, aluminum foil, tweezers, desiccator, oven, electric stove, furnace ashing, 42 Whatman filter paper ash-free, fat-free cotton, pumpkin fat, condenser, Soxhlet tube, water bath, Kjeldahl flask, distillation, Erlenmeyer flasks, burette, volumetric pipette, micro pipette, Pasteur pipette, measuring cup, orbital shaker, rotary vacuum evaporator, UV-Vis spectophotometric, setrifuse cold, AMP diagnostic kits ${ }^{\circledR}$.

\section{Procedure Analysis of Research}

This study consisted of several stages, namely the stage of preparation and characterization sample of mangrove fruit (Rhizhopora mucronata), extraction, phytochemical analysis, and testing of hepatoprotective effect of mangrove fruit extracts in vivo.

2.1 Preparation and Extraction (Ravikumar \& Gnanadesigan 2012 and Nurdiani et al. 2012)

Sample of mangrove fruit (Rhizophora mucronata) taken from Mangrove Forest Conservation in Pantai Indah Kapuk area. Once the sample is obtained, further their cleaned from impurities by using akuades, then put the mangrove fruit samples in plastic bags that have been labeled.

sample was made be fine powder by blender. Fine powder which was prepared and then used for proximate analysis (AOAC 2005) and extracted using 95\% ethanol (polar) (Ravikumar \& Gnanadesigan 2012). Samples were extracted by maceration method. $50 \mathrm{~g}$ of mangrove fruit powder (R. mucronata) soaked in $250 \mathrm{ml}$ of $95 \%$ ethanol (1:5) (b:v) in a 500 $\mathrm{ml}$ erlenmeyer flask for 24 hours. Then the extract filtered with Whatman filter paper no. 42, 
the resulting filtrate was eliminated the solvent with a rotary vacuum evaporator at a temperature of $40^{\circ} \mathrm{C}, 50^{\circ} \mathrm{C}, 60^{\circ} \mathrm{C}, 70^{\circ} \mathrm{C}$ and $80^{\circ} \mathrm{C}$. The results of the extraction produced crude extract then weighed to obtained the extract. Results extract stored in sealed bottles until used for analysis of phytochemicals, antioxidants analysis, and analysis of testing hepatoprotective effects in vivo (Sengupta et al. Ravikumar \& Gnanadesigan 2011 and 2012).

\subsection{Proximate Analysis (AOAC 2005)}

Proximate analysis is an analysis that is performed to determine the chemical composition of a material include, analysis of water content, fat, protein, and ash.

2.3 Testing of antioxidant activity (Hanani et al. 2005 with modified)

The antioxidant activity of the crude extract of the mangrove fruit (Rhizophora mucronata) was determined by the 1,1-diphenyl-2-picrylhdrazyl (DPPH) method based on Hanani et al. 2005 with modified. The initial phase of testing of antioxidant activity was to prepared the sample solution. Sample of crude extract of the mangrove fruit dissolved in methanol with concentration of $0.781,1.562,3.125,6.25,12.5$, and 25 ppm. Vitamin super ester $C$ used as a positive control, and for comparison with each concentration of $2,4,6,8$, and 10 ppm.

Blanco solution with a concentration of $125 \mu \mathrm{M}$ was made using crystalline DPPH dissolved in ethanol p.a. DPPH solution preparation process performed under conditions protected from sunlight. Antioxidant activity test performed by based on the ability of the samples that used in reducing DPPH free radical. Positive control using 100 ppm of ascorbic acid solution was made by dissolving Vitamin $C$ crystals in ethanol p.a. DPPH solution with a concentration of $125 \mu \mathrm{M}$ was taken as much as $100 \mu \mathrm{M}$ and $100 \mu \mathrm{M}$ the extract, then put in a microplate that had been prepared. The solution mixture was homogenized and incubated at $37{ }^{\circ} \mathrm{C}$ for 30 minutes. The resulting absorption was measured using a Microplate Spectrophotometer EpochTM at a wavelength of $517 \mathrm{~nm}$. A compound can be said that have antioxidant activity when the compound is able to donated hydrogen atom that are marked by purple color changes to yellow (Molyneux 2004). After that, the antioxidant activity from each sample and comparison of antioxidant BHT expressed by percent inhibisi which calculated with the following formula :

$\%$ Inhibisi $=\frac{\text { Absorbansi blanko-Absorbansi sampel }}{\text { Absorbansi blanko }} \times 100 \%$

Concentration sample value (extracts and antioxidant comparison Vitamin C) and the percent of inhibisi was plotted of each on the $x$ and $y$ axis on the linear regression equation. The linear regression equation obtained in the form of the equation $y=a+b x$ that is used to find the value of the IC50 (inhibitor concentration 50\%) from each sample with a stated value of $y$ is 50 and the value of $x$ that will be obtained as IC50. IC50 values stated the 
concentration of the sample solution (extract and antioxidant BHT comparison) that required to reduce DPPH free radicals in amount of $50 \%$.

\subsection{Phytochemicals Test (Harborne 1984)}

Phytochemical test on mangrove fruit extract mucronata performed to determined the content of secondary metabolite which are expected can function as hepatoprotective. Phytochemicals test include alkaloid test, steroid/ triterpenoid test, flavonoid, saponin, phenol hydroquinone, Molisch, Benedict, Biuret and Ninhydrin. These test method is based on Harborne (1984).

2.5 Hepatoprotective effect test in vivo (Sengupta et al. Ravikumar \& Gnanadesigan 2011

and 2012)

Hepatoprotective effect test using Sprague Dawley male rat. Before the experiment started all experimental animals was acclimatized for approximately seven days to adapted the new environment. During the acclimatization period, the experimental animals were fed a standard feed and drink ad libitum. On the last day adaptation of rats were weighed and divided into 7 groups $(n=3)$ in a separate enclosure. The treatment group as follows:

1. Normal : Negative control (normal)

2. $\mathrm{CCl} 4$ : Positive controls, rat was induced by $\mathrm{CCl} 4$ with a dose of $2 \mathrm{ml} / \mathrm{kg} \mathrm{BB}$ (diluted $1: 1(\mathrm{v} / \mathrm{v})$ in liquid paraffin) by intraperitonial on the first day.

3. El : Rhizophora mucronata extract treatment. Rat was induced on the first day (Group 1), then was given selected mangrove fruit extract with concentration of $1 \mathrm{mg} / \mathrm{kg}$ dissolved in $0.5 \%$ Tween 20 orally induced on day 2 until day 8 .

4. E5 : Equal treatment with group 3. Doses Rhizophora mucronata extract was performed $5 \mathrm{mg} / \mathrm{kg} \mathrm{BB}$.

5. E15 : Equal treatment with group 3. Doses Rhizophora mucronata extract was performed $15 \mathrm{mg} / \mathrm{kg} \mathrm{BB}$.

6. E25 : Equal treatment with group 3. Doses Rhizophora mucronata extract was performed $25 \mathrm{mg} / \mathrm{kg}$ BB.

7. Syl : standard hepatoprotective treatment, sylimarin. rat was induced

On the first day, then was given sylimarin (dissolved in $0.5 \%$ Tween 80 ) dose of $25 \mathrm{mg} /$ $\mathrm{kg} \mathrm{BB}$ orally on day 2 until day 8 . After 36 hours of treatment all rats were sacrificed by euthanasia intraperitoneal with ketamine, and blood samples were taken from the heart, to get the blood serum, blood samples were obtained then was centrifuged at $3000 \mathrm{rpm}$ for 10 15 minutes (Panjaitan 2007). Blood samples were used to analyze the levels of AST enzyme and ALT enzyme (AMP diagnostic kits ${ }^{\circledR}$ ), whereas liver for preparations observation of liver histopathology (Panjaitan 2007) and analysis of MDA levels (Alexander et al. 2009). 


\section{Analysis of Data}

Data analysis was performed on the enzyme levels of AST and ALT serum, and MDA levels. The design that are used was completely randomized design (CRD). RAL observation model, as follows:

$$
Y_{i j}=\mu+\alpha i+\Sigma i j
$$

Description:

$$
\begin{aligned}
Y i i & =\text { effect response of treatment on the level } i \text { to } i \text { replicates } \\
\mu & =\text { the average effect of general } \\
\alpha i & =\text { effect of treatment on the level } i \\
\Sigma i j & =\text { random effect (error trials) on concentration level } i \text { repeat } i \\
J & =1,2, \text { and } 3 ;
\end{aligned}
$$

If the results of the test showed a significantly different effect on the interval of $95 \%$ ( $\alpha=$ 0.05 ) so that performed a further test of Duncan. Duncan test formula is:

$$
\mathrm{Rp}=\mathrm{r}\left(\sum \mathrm{p} ; \mathrm{dbs} ; \mathrm{a}\right) \sqrt{\frac{\mathrm{kts}}{\mathrm{r}}}
$$

\section{RESULTS AND DISCUSSION}

\section{The Antioxidant Activity of Mangrove Fruit (R.mucronata)}

Antioxidant is defined as compound that can delay, slow down, and prevents the oxidation of fat (Suhartono et al. 2002). Furthermore, according to Handy and Sulistyo (2008), antioxidant potential to inactivate free radicals by donating one or more mechanisms of electrons, so that the free radicals can be muted. Antioxidant mechanism also enables the stabilizer properties of free radical molecules produced by various types of the body's normal chemical processes or by solar radiation, cigarette smoke, and other environmental influences.

The antioxidant activity of mangrove fruit extract (R.mucronata) expressed as a percentage resistor of DPPH free radicals. Comparative antioxidant used in this study was Vitamin $C$ as an standard antioxidant which is a pure compound that resistor of DPPH radical more effectively with low concentration. Antioxidant activity from samples indicated by a color change in the DPPH solution which initially concentrated purple to a bright yellow. According Andayani et al. (2008) the presence of the antioxidant activity from samples resulted color change of DPPH solution in ethanol which initially concentrated purple to yellow. Tested antioxidant analysis of mangrove fruit (R.mucronata) using 5 different extracts evaporation temperature treatment such are a temperature of $40^{\circ} \mathrm{C}, 50^{\circ} \mathrm{C}, 60^{\circ} \mathrm{C}, 70^{\circ} \mathrm{C}$, and $80^{\circ} \mathrm{C}$. The results test of antioxidant activity of mangrove fruit (R.mucronata) and Vitamin $\mathrm{C}$ presented in Figure 4. 


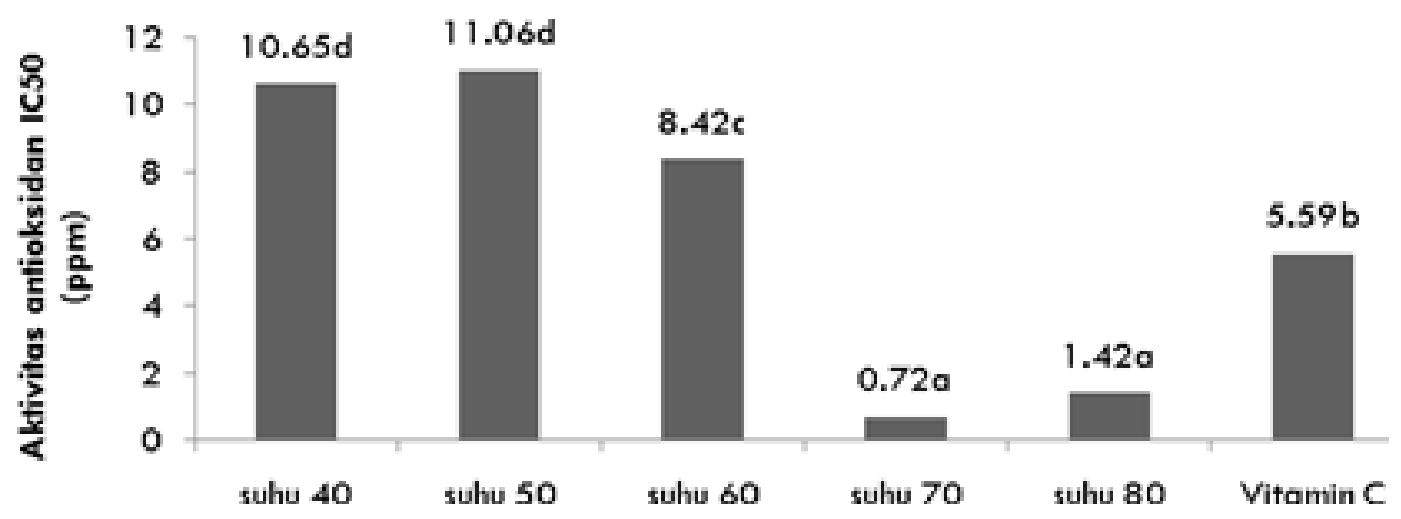

Figure 3 Average Value of antioxidant activity of mangrove fruit crude extract (R.Mucronata) with evaporation temperature treatment

The results analysis of antioxidant activity in Figure 3 showed the evaporation temperature treatment of mangrove fruit extract has given significantly effected $(p<0.05)$ on the antioxidant activity of mangrove fruit samples. Based on results of Duncan continued test obtained the most antioxidant activity was in $70^{\circ} \mathrm{C}$ temperature with IC 50 value in the amount of $0.72 \mathrm{ppm}$. The results of antioxidant activity in $70^{\circ} \mathrm{C}$ temperature treatment were significantly different $(p<0.05)$ at $40^{\circ} \mathrm{C}$ temperature treatment, $50^{\circ} \mathrm{C}, 60^{\circ} \mathrm{C}$, and Vitamin $\mathrm{C}$, but not significantly different in $80^{\circ} \mathrm{C}$ treatment temperature. Standard antioxidant used in this study was Vitamin C with IC50 value in amount of $5.59 \mathrm{ppm}$. Research performed by Banerjee et al. (2008) showed Ascorbic acid IC50 value in amount of $3.62 \mathrm{ppm}$. The results of antioxidant activity test showed mangrove fruit (R.mucronata) was a powerful antioxidant compound, because all treatments had IC50 value less than 50 ppm. According to Molyneux (2004), a material with IC50 value $<50$ ppm was a very powerful antioxidant.

The antioxidant activity of mangrove fruit on $70^{\circ} \mathrm{C}$ temperature treatment is the best treatment with the IC50 value in amount of $0.72 \mathrm{ppm}$, even better than Vitamin C. That value is not different from the Bunyapraphatsara's research (2002) antioxidant activity DPPH method on mangrove fruit (R.mucronata) in Thailand obtained IC50 value in amount of 4.33 ppm. Further research performed by Priyatno (2012) with the same sample, obtained IC50 value mangrove fruit methanol extract (R.mucronata) in amount of $58.61 \mathrm{ppm}$. Based on Figure 3 discovered the higher evaporation temperature was used then the resistor IC50 value the better. It was alleged that treatment evaporation temperature of $70{ }^{\circ} \mathrm{C}$ was the optimum temperature of antioxidant separation processes on mangrove fruit. The higher evaporation temperature was used, chemical component on some materials was separated or perfectly extracted in optimum condition. This is consistent with the results of Maulida et. al's research (2010), stated in the antioxidant extraction (lycopene) from tomato, which at a temperature of $70^{\circ} \mathrm{C}$ lycopene antioxidant from tomato has separated from the cell structure of tomato. 
The higher antioxidant nature in ethanol extract of mangrove fruit alleged correlated with the number of active compound that can be detected by phytochemical test. Bioactive components in ethanol extract of mangrove fruit include the flavonoid, tannin, saponin, and hydroquinone phenol. That compound has antioxidant activity. Furthermore, according to Ravikumar \& Gnanadesigan (2012) said that the presence of chemical compound such as flavonoid, triterpenoid, tannin, and alkaloid which exist on the underlying causes of mechanism antioxidant of mangrove fruit in rat was induced by $\mathrm{CCl}_{4}$. According to Rohaeti et al. (2010) mangrove fruit also has several active compound, namely flavonoid, saponin, tannin, and triterpenoid which have function as antioxidant compound. Evaporation temperature treatment also effected to the specific bioactive components that caused the antioxidant activity of mangrove fruit was high. Francil et al. (1985) stated that the class of phenolic compound was relatively resistant to heat whereas according Kikukagawa et al. (1990) although the phenolic compound can be degraded by high heat and turn into antioxidant dinner, but still has a high antioxidant activity.

\section{Bioactive Components of Mangrove Fruit Extract (R.mucronata)}

The sample used was a crude extract of mangrove fruit. Qualitative phytochemical screening performed as the initial test to determined the presence of specific chemical compound, compound secondary metabolit which are expected to acted as antihepaototoksik. This Phytochemical screening was based on the method of Harborne (1987). The result of Phytochemical analysis test can be seen in Table 3.

Phytochemical test results in Table 3 indicated that the crude extract of mangrove fruits contain alkaloid, flavonoid, tannin, saponin, and hydroquinone. Samples alkaloid test showed positive result in wagner and dragendorf reagent. The presence of flavonoid was shown by the formation of an orange solution. Tannin was indicated by the formation of a concentrated green solution. The saponin was indicated by presence of steady foam after was settled for 10 minutes in the reagent. Hydroquinone showed the presence of a phenol compound in the material by the formation of a green color.

Tabel 3 The result of Phytochemical crude extract of mangrove fruit

\begin{tabular}{llc}
\hline & Uji & Hasil \\
\hline \multirow{2}{*}{ alkaloid } & Wagner & Meyer \\
& Dragendorf & - \\
Steroid & & - \\
Flavonoid & - \\
Tanin & + \\
Saponin & + \\
Tripernoid & + \\
Hidroquinon & - \\
\hline
\end{tabular}

Flavonoid are known as antioxidant that have the potential to treat diseases caused by free radical. According to Redha (2010) the antioxidant activity of flavonoid rooted from the 
ability to donated hydrogen atom or through its ability to chelated metal. Flavonoid was a good reducing compound, inhibiting oxidation reactions, both enzymatic and non- enzymatic. Alkhali and Bandy (2009) stated, as an antioxidant flavonoid which inhibited some oxidizing enzymes performance such as xanthine oxidase, and chelated metal so it can be prevented the occurrenced of redox reactions that can produce free radical. According to Miller (1996), a number of medicinal plants contained flavonoid have antioxidant activity, antibacterial, antivirus, anti-inflammatory, and hypo-allergenic.

Tannins are complex polyphenolic compound that was widespread in plants, especially vascular plant (Harborne 1987). Hagerman (1998) stated that the tannin have the ability to captured free radical. Tannin are very effective as an electron/ hydrogen atom donor and chelating metal, because these compound have a hydroxyl group and conjugated double bond that was allow the electron delocalization.

Saponin are surface active compound and nature like soap and can be detected by their ability to formed foam. Xiong et al. (2010) stated these compound was antioxidative and scavenger radical with formed hidroperoxida as an intermediate compound and can donated hydrogen in DPPH radical compound so can terminated radical chain reaction. The levels of saponin in plants and drugs have some kind of bioactivity, such as antivirus, anti-inflammatory, and antiparasitic (Navarroa et al. 2001), and improved the immune system and anticancer (Estrada et al. 2000).

Phenolic component are aromatic structure that binds to one or more hydroxyl group and nature water soluble (Haborne 1984). The result of phytochemical screening showed the crude extract of mangrove fruit showed hydroquinone phenolic component that alleged antioksidant activity. Hydroquinone and its compound have function as oxidative resistor to bind free radical and reacted with Reactive Oxygen Species (ROS) compound to formed a more stable compound (Eastman 2009).

\section{Levels of AST and ALT Rat Serum}

Liver have many function, one of them is a function of detoxification. Liver was responsible for the biotransformation of hazardous substances (eg drugs) into not harmful substances then excreted by the kidney. Liver cells was organell rich cells and contained a variety of enzymes, some of them was important to diagnostic because was supplied to the blood vessel and its activity can be measured so can showed the presence of liver disease or severity levels (Ganong 2002).

Tissue liver contained transaminase enzymes in amount large like aspartate transaminase (AST) serum enzymes and alanine transaminase ( ALT ) that can be used as indicator of liver damage, because both enzymes will prior increased more evident if compared with other enzymes in the liver (Sujono 2002). The measurement results of levels of AST and ALT rat blood on strain Sprague-Dawley male rat serum $(n=3)$ with 7 treatments of rats group namely, normal, CCl4, $1 \mathrm{mg} / \mathrm{kg}$ extract, $5 \mathrm{mg} / \mathrm{kg}$ extract, $15 \mathrm{mg} / \mathrm{kg}$ BB ekstract, $25 \mathrm{mg} / \mathrm{kg}$ BW ekstract, and Sylimarin was presented in Figure 5. 

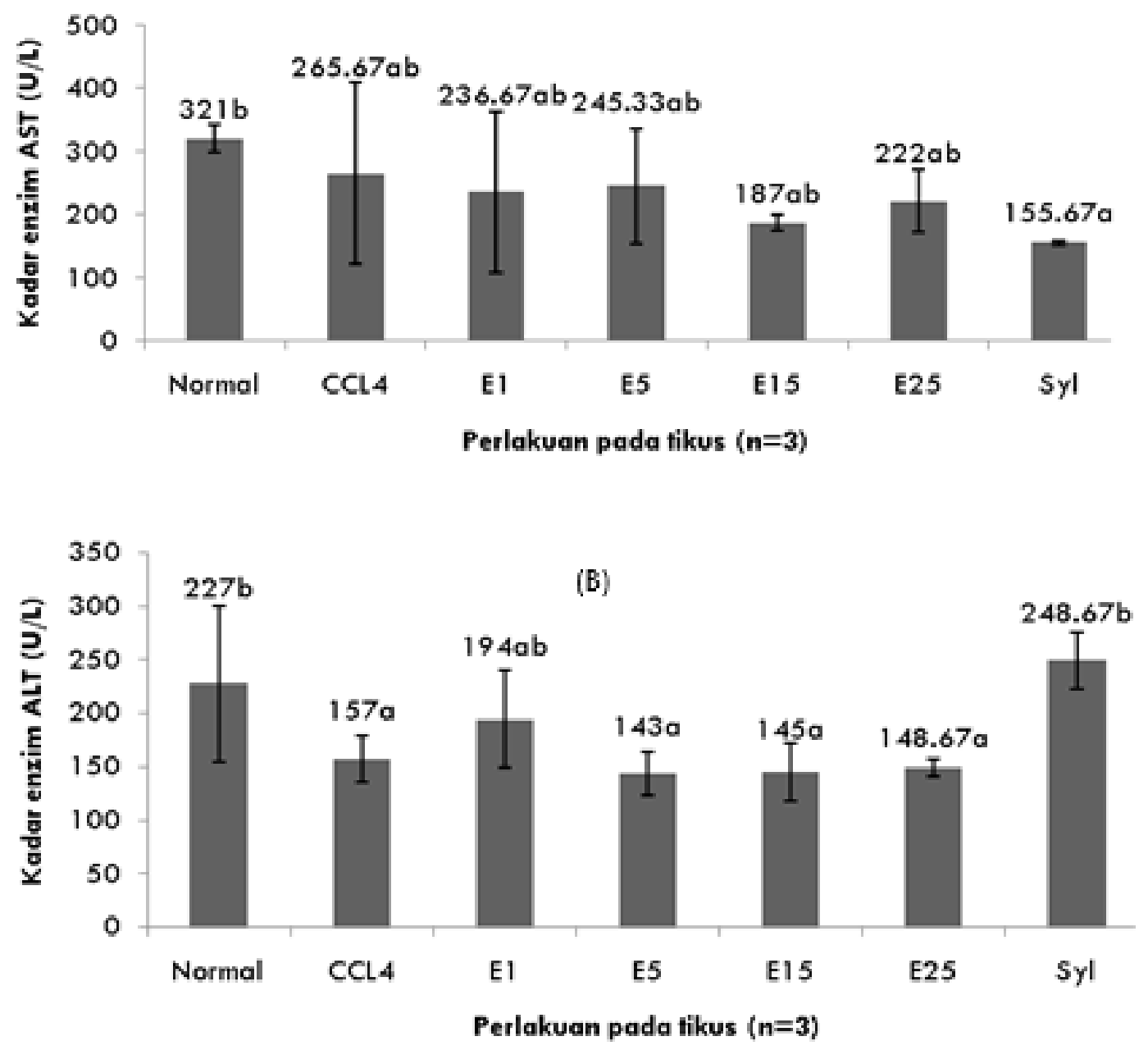

Figure 5. Measurement mean of levels of AST (A) enzymes and ALT (B) enzymes on Sprague Dawley male rat serum $(n=3)$

After giving mangrove fruit extract (R.mucronata) during 7 days of treatment in Figure 5, can be seen AST levels in all extract treatment (E1 to E25) didn't showed significantly different results $(p>0.05)$, but it given significantly different change $(p<0.05)$ with the normal treatment group and sylimarin. From the results of Duncan continued test can be seen the most average declined of AST levels was the E15 treatment, namely the provision of the $15 \mathrm{mg} / \mathrm{kg}$ BW extract with AST enzymes levels in amount of 187 U/ L. According to Sari et al. (2008) the increased of aminotransaminase activity in serum was an indicator of damage that occured in the liver cells, especially acute damage. This is in line with the statement of Giannini et al. (2005), the indicated of occurred acute disease was aminotransaminase increased more than 20 times from the normal levels.

Statistical analysis showed that the treatment given to rat significantly effected in serum ALT enzymes levels. E1 treatment had significantly different result $(p<0.05)$ among other treatments. The most average decreased of serum ALT levels was the E5 treatment in amount of $157 \mathrm{U} / \mathrm{L}$ more lower than $\mathrm{CCl} 4$ giving group and was significantly different $(p<0.05)$ than the normal treatment group. This means that the giving of ethanol extract of mangrove fruit (R.mucronata) was able to provided protection against the damage in the liver cells. 
The decreased of serum AST enzymes levels in rats groups were given extracts of mangrove fruit (R.mucronata) allegadly related to the content of bioactive component that contained in the extract namely, flavonoid, tannin, saponin, and hydroquinone phenol which acted as an antioxidant. These results was in line with Ravikumar and Gnanadesigan (2012) research, stated that mangrove fruit extract (R.mucronata) can reduce levels of the serum AST and ALT enzymes from rat which significantly induced of CCL4 $(p<0.05)$ from the positive treatment group, the declined of AST levels was caused by the presence of a chemical compounds of flavonoid class, tannin polyphenolic, and alkaloid. The possible hepatrotektif mechanism in mangrove fruit (R.mucronata) caused by the bioactive compound did P450 cytochrome resistor to produce triklorometilperoxi ( $\left.\mathrm{CCL} 3^{*}\right)$ free radical $\mathrm{CCl} 4$ metabolism results. The content of saponin, tannin, and steroid may help repaired liver cells and decreased the activity of AST and ALT serum by a variety of mechanisms including; increased of inhibited fat concentrations, inhibited free radical mutation process, induced the antioxidant enzymes, and became electron donor in free radical to be more stable (Batubara 2003; Yen and Hui 1995; Wang et al. 2003).

Based on Figure 5 , the positive control of $\mathrm{CCl} 4$ treatment group in both AST and ALT enzymes levels showed a significantly more lower result $(p<0.05)$ than the normal group. The giving of CCL4 should be increased the levels of serum AST and ALT enzymes from normal group because the nature of free radicals can damaged liver cells. The research of Venukumar and Latha (2002) with Sprague Dawley rat showed that the giving of $\mathrm{CCl} 4$ resulted an increased of average AST and ALT enzymes levels. The damage in little relatively in the liver cells will increase the levels of AST and ALT enzymes in blood serum. However, if the level of damage was more severe or have an acute nature, allegedly availability of AST and ALT enzymes in liver cells is very low due to liver cells not able to synthesize both of these enzymes. According to Panjaitan et al. (2007) the giving of CCl4 dosing too high in Sprague Dawley rat can caused widespread damage, so that the availability of ALT and AST enzymes in liver cells was very low due to the ability of liver cells to synthesize aminotransaminase enzymes has been reduced or dissapear altogether. Carbon tetrachloride $(\mathrm{CCl} 4)$ is xenobiotics which very toxic on liver cells, the result of $\mathrm{CCl} 4$ biotransformation in liver cells will formed triklorometil and triklorometilperoxi which reactive nature so that can caused peroxidation of fat and cell death (Hudgson 2004).

\section{Levels of MDA in Rat Liver}

Malondialdehyde (MDA) is the end result of free radical attack on the integrity of cellular component. The most susceptible of cell component to free radical attack is the cell membrane that containing the poly unsaturated fatty acids (PUFA). Free radicals will caused a fat peroxidation in these PUFA components with the end result of malondialdehyde (MDA). The Changes of MDA levels showed a changes in the free radicals activity (Alexander et al. 2009). MDA levels in liver from rats group that was given treatment are presented in Figure 6 and an example of calculation is presented in Appendix. 


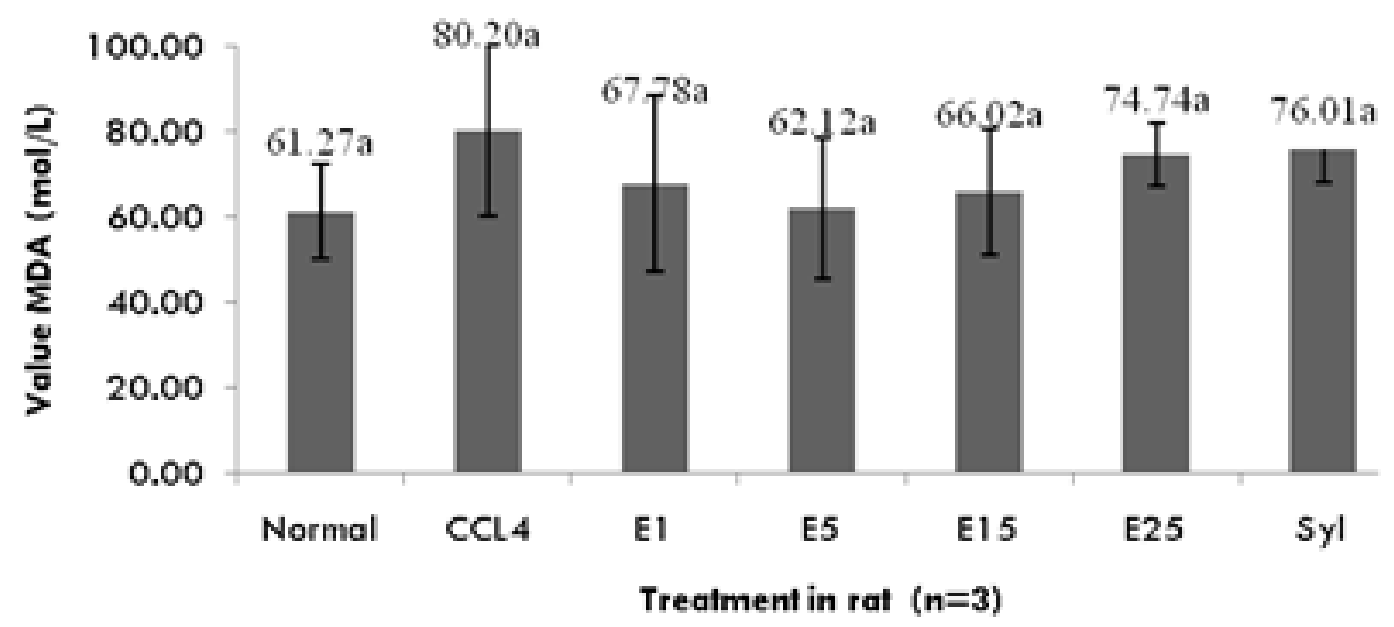

Figure 6. Mean of measurement levels of MDA in rat liver

Statistical analysis showed that the treatment that was given to rat caused changes in MDA levels were not significantly different $(P>0.05)$. The giving of ethanol extract of mangrove fruit (R.mucronata) and sylimarin in curative caused the decreased of liver MDA levels, but the levels still higher than the level of liver MDA group of normal rats. These showed that the indication of the improvement and protection of the liver damage which caused by $\mathrm{CCl} 4$ ethanol extract of mangrove fruit. The best of decreased levels of MDA was found in the group treatment of E5 with mean in amount of $62.12 \mathrm{~mol} / \mathrm{L}$. .

The Giving of $\mathrm{CCl} 4$ in white rat caused the increased of malonaldialdehid (MDA) levels in rat liver. According to Lili et al. (2006) have reported that was an increased of fat peroxidation in liver tissue and muscle rat after induction of carbon tetrachloride that was measured using TBARS test. Carbon tetrachloride $(\mathrm{CCl} 4)$ will metabolized in the liver by cytochrome P450 enzymes to form triklorometil radical that can reacted further with taken hydrogen donors on PUFA in cell membrane produced chloroform metabolite and fat acid radical that can have further reaction if there is oxygen. The Increased of peroxidation of fat associated with antioxidant defense which caused by the failure of antioxidant mechanism to prevent free radical formation. One of the products was formed during fat peroxidation is MDA (Timbrell 2002). Malonaldehida can caused the damage of hepatosi in a chain (Auroma 1997). To prevent of damage which caused by free radical, the tissue already has the antioxidant defense system that includes a non - enzymatic antioxidant (bilirubin, vitamins $C$ and $E$, glutathione) and enzymatic antioxidants such as superoxide dismutase (SOD), catalase, glutashione peroxidase (GPX). According to Uzma et al. (2011) peroxidation of fat which caused by $\mathrm{CCl} 4$ cause an increased of free radical, MDA levels, and depletion of glutathione levels. These is in line with research of Alzoghaibi and Bahamman (2007) who reported a derivative product of fat peroxidation in patients with asthma like MDA can given the effect 
of crosslinking on membrane protein, membrane receptors error, and facilitated antioxidant enzymes become inactive.

The resistor effect of fat peroxidation in ethanol extract of mangrove fruit is allegedly related to the flavonoid compound antioxidant, steroid, tannin, saponin, and phenol that contained in there. Bioactive compound especially contained phenolic group have the ability of antioxidant that can prevent fat peroxidation so that can reduce the formation of fat peroxidation products such as malonaldehida (Arafat 2005). According Durgo et al. (2007) derivative flavonoid compound such as queretin, myricetin, and luteolin can decreased toxic compound and MDA levels in vivo by inhibited the activity of cytochrome P450 mechanism. Other research by Khennouf et al. (2010) phenolic component such as flavonoid (catechin and kuertesin) and some tannin derivative (kastalagin and akutisimin) positives became radical scavenging at the initiation stage of resistor fat peroxidation. According to Gong et al. (2012) hepatoprotective effect of Mitragyna rotundifolia herbal extract related with antioxidant nature in inhibited fat peroxidation and prevent disruption of antioxidant enzymatic activity.

\section{CONCLUSION}

Positif fruit mangrove ( $R$, mucronata) has antioxidant and hepatoprotective activities so that could potentially to be a preparation of functional food. From the research of mangrove fruit which used in this studied has the optimum antioxidant activity which obtained from $70^{\circ} \mathrm{C}$ evaporation temperature treatment with IC50 values in amount of $0.72 \mathrm{ppm}$. The result of phytochemicals test showed that the crude extract of mangrove fruits contained alkaloid, flavonoid, tannin, saponin, and hydroquinone. Ethanol extract of R.mucronata mangrove fruit that was given orally to rat which had been induced by $\mathrm{CCl}_{4} 0.2 \mathrm{ml} / \mathrm{kg} \mathrm{BB}$ can decreased the levels of AST and ALT enzymes and MDA levels of rat liver. Hepatoprotective effect of ethanol extract of mangrove fruit allegedly have strong associated with antioxidant activity from bioactive components which contained in it.

This study still using a crude extract that still containing other compounds which are not the antioxidant compound, therefore it need purification from the crude extract and antioxidant testing from pure extract. Identification of other bioactive compound which found in the mangrove fruit and determination of phenolic and flavonoid class of compound extracted to be know the specific compounds that trigger the antioxidant and hepatoprotective.

\section{REFERENCES}

[WHO] World Health Organization. 2012. WHO | Hepatitis countries area at risk. www.who.int [15 Juli 2013]

Alkhali $M$, Bandy B. 2009. Mechanism of flavonoids protection against myocardial ischemiareperfusion injury. J. molec. And Cellul. Cardiology. 46:309-317

Alzoghaibi $M$ dan Bahammam A. 2007. Lipid peroxidation in stable asthmatic receiving inhaled steroid and long-acting-aginist. Respirology 12:439-442.

Andayani $R$, Lisawati $Y$, Maimunah. 2008. Penentuan aktivitas antioksidan, kadar fenolat total dan likopen pada buah tomat (Solanum Lycopersium L.). Jurnal Sains dan Teknologi Farmasi 13(1):1-9. 
Arafah E. 2007. Perlindungan dan efek penyembuhan sediaan bangle (Zingiber cassumunar) terhadap perdangan hati tikus serta mekanismenya pada sel makrofag dan limfosit. [Tesis] Sekolah Pascasarjana, Institut Pertanian Bogor.

Atta-au-rahman, MI Coudhary. 2001. Bioactive natural product a potential of pharmacophorus. A Theory of Memory. Pure and Applied Chemistry. 73(2):555-560.

Brick J. 2004. Medical consequences of alcohol. www.rutgers-uni.ac.us. [02 Januari 2013].

Batubara I. 2003. Saponin akar kuning (Archaengelisia flava (L) Merr.) sebagai hepatoprotektor: ekstraksi, pemisahan, dan bioaktivitasnya. [Tesis]. Bogor: Jurusan Kimia FMIPA IPB.

Durgo et al. 2007. Effectk of flavonoids on glutathione lev, lipid peroxidation, and cytochrome P450 CYP1Al expression in human laryngeal carcinoma cell lines. Food Technol. Biotechnl 45(1): 69-79

Eastman. 2009. Hydroquinonen and Hydroquinon Derivates. Canada: Eastman Chemical Company

Estrada A, Katselis GS, Laarveld B, Barl B (2000). Isolation and evaluation of immunological adjuvant activities of saponins from Polygala senega L. Comp. Immunol. Microbiol. Infect. Dis. 23:27-43

Ganong F. 2002. Buku Ajar Fisiologi Kedokteran. Ed ke-20. Djauhari HM, penerjemah. Jakarta: EGC. Teriemahan dari Review of Medical Physiology.

Gong F, Yin ZH, Xu Q, dan Kang W. 2012. Hepatoprotective effect of Mitragyna rotundifolia kunteze on CCL4-induced acute liver injury in mice. Journal of Pharmacy and Pharmacology 6(5): 330-335.

Hagerman AE. 1998. . High molecular weight plant polyphenolics (tannins) as biological antioxidants. Journal of Agricultural and Food Chemistry $46: 1887-1892.76$.

Handayani R, Sulistyo J. 2008. Sintesis senyawa flavonoid- $\alpha$-glikosida secara reakasi transglikosilasi enzimatik dan aktivitasnya sebagai antioksidan. J Biodiversitas 9:1-4.

Hartono,Nurwati I, Ikasari F, dan Wiryanti. 2005. Pengaruh ekstrak rimpang kunyit terhadap peningkatan kadar SGOT dan SGPT tikus putih akibat pemberian asetaminofen. Biofarmasi 3(2): 57-60

Hodgson E. 2004. A Textbook of Modern Toxicology, Third Edition. North Carolina State University: A JOHN WILEY \& SONS, INC., PUBLICATION.

Jacoeb A M, Hamdani $M$, Nurjanah. 2008. Perubahan komposisi kimia dan vitamin daging udang ronggeng (Harpiosquilla raphidea) akibat perebusan. Buletin Teknologi Hasil Perikanan. $11(2): 76-88$.

Jeon TI, Hwang SG, Park NG, Shin SI, Choi SD, Park DK. Toxicology 187 (2003) 67-73. (Science direct Antioxidant chitosan on chronic).

Khennouf S, Amira S, Arrar L, dan Baghiani A. 2010. Effect of some phenolic compounds and quercus tannins on lipid peroxidation. World Applied Sciences Journal 8(9): 11441149.

Kementerian Kesehatan Republik Indonesa. 2012. Data dan Informasi, Hepatitis. www.depkes.go.id [15 Juli 2013]

Matkowski A. 2008. Plant in vitro culture for the production of antioxidants. Biotech Adv. 26:548-560

Miller N. J. \& Evans C. A. 1996. Antioxidant activites of flavonoids as bioactive components of food. Biochemical Society Transactions 24: 790-795.

Molyneux P. 2004. The use of stable free radical diphenylpicrylhydrazyl (dpph) for estimating antioksidan activity. Songklanakarin Journal Sciences Technology 26(2):211-219.

Navarroa P, Ginera RM, Recioa MC, Máñeza S, Cerdá-Nicolás M, Ríosa JL (2001). In vivo anti-inflammatory activity of saponins from Bupleurum rotundifolium. Life Sci., 68: $1199-1206$.

Nugraha AS, Hadi NS, Siwi SU. 2008. Efek hepatoprotektif ekstrak buah merah (Pandanus conoideus Lam.) pada hati mencit jantan galur swiss induksi dengan CCL4. Jurnal Natur Indonesia 11 (1): 24-30.

Nurdiani R, Firdaus M, Prihanto AA. 2012. Phytochemical screening and antibacterial activity of methanol extract of mangrove plant (Rhizophora mucronata) from Porong River Estuary. Journal Basic Science And Technology. 1(2): 27-29.

Panjaitan et al. 2007. Pengaruh pemberian karbon tetraklorida terhadap fungsi hati dan ginjal tikus. Makaira, Kesehatan, Vol (2): 11-16 
Priyatno A. Aktivitas antioksidan dan komponen bioaktif pada buah bakau (Rhizophora mucronata Lamk.). [Skripsi] Departemen Teknologi Hasil Perairan, Fakultas Perikanan \& Ilmu Kelautan, Institut Pertanian Bogor.

Ravikumar S dan Gnanadesigan M. 2012. Hepatoprotective and antioxidant properties of rhizophora mucronata mangrove plant in $\mathrm{CCl} 4$ intoxicated rats. J exp Clin Med 4 (1): 66-72

Redha A. 2010. Flavonoids: Struktur, sifat antioksidatif dan pernanya dalam sistem biologis. Jurnal Belian 9(2): 196-200.

Rohaeti et al. 2010. Potensi ekstrak rhizophora sp. sebagai inhibitor tirosinase. Prosiding Seminar Nasional Sains (3).

Sengupta et al. 2011 . Hepatoprotective and immunomodulatory properties of aqueous extract of Curcuma longa in carbon tetra chloride intoxicated Swiss albino mice. Asian Pacific Journal of Tropical Biomedicine: 193-199.

Suhartono E, Fujiati, Aflanie I. 2002. Oxygen toxicity by radiation and effect of glutamic piruvat transamine (GPT) activity rat plasma after vitamin $C$ treatment. Diajukan pada International.

Sujono H. 2002. Gastroenterology. Bandung: Penerbit Alumni.

Timbrell j. 2002. Principles of biochemical toxicology. Ed ke-3. Taylor \& Francis Inc. USA.

Uzma N, Kumar S, dan Aness S. 201 1. Red wine ameliorates CCL4-induced acute liver injury in rats. Austrakian Journal of Biomedical Science 1(1):1-7

Venukumar MR, MS Latha. 2002. Hepatoprotective effect of the methanol extract of Curligo orchioides in CCL4 treated male rats. Indian Journal of Pharmacology 34:260-275

Wang L. Yen JH, Ling HL, Wu MJ. 2003. Antioxidant effect of methanol extract from lotus plumule and blossom (Nelumbo nucifera Gertn.). J Food Drugs Anal 11: 60-66.

Xiong et al. 2012. preparation and biological activity saponin ophiogon japonicas. African Journal of Pharmacy and Pharmacology 6(26): 1964-1970

Yen GC, Hui YC. 2005. Antioxoidant activity of various extract in relation of their antimutageneticity. 